\title{
MICROBIOLOGICAL ANALYSIS OF DRIED GOOSE CARCASSES
}

\author{
Ufuk Kamber ${ }^{1}$, Hilmi Yaman² \\ ${ }^{1}$ Food Safety and Health Department, Veterinary Faculty, \\ Kafkas University, Kars, Turkey \\ ${ }^{2}$ Nutrition and Dietetics Department, School of Health Sciences, \\ Adnan Menderes University, Aydin, Turkey
}

Received 1 December 2015; Received in revised form 11 January 2016; Accepted 28 February 2016

\begin{abstract}
Microbiological studies on chicken meat and carcasses are well documented, but very few studies exist on goose meat and carcasses. Therefore, in this study, dried goose carcass samples were collected from the local households in Kars/Turkey and microbiologically analyzed in terms of public health risks. The total mesophilic viable count was found to be 6.58 (mean $\left.\log 10 \mathrm{CFU} \mathrm{g}^{-1}\right)(100 \%)$. The number of Enterobacteriaceae was $4.85(92.8 \%)$. Coliform bacteria was counted at the numbers of $2.98(67.8 \%)$, while it was $3.95(91.1 \%)$ for the enterococci, $0.42(26.7 \%)$ for the clostridia, $0.04(3.5 \%)$ for the Clostridium perfringens, and $0.41(12.5 \%)$ for the coagulase positive staphylococci. The numbers of mould and yeast were $0.93(25 \%)$ and $4.81(94.6 \%)$, respectively. Salmonellae and Bacillus cereus could not be isolated in the samples. The results indicate that the dried goose meat samples had poor hygienic quality, contained some of the pathogen microorganisms that are likely to pose a potential health risk.
\end{abstract}

Key words: goose, poultry, dried meat, carcass, microbiological quality

\section{INTRODUCTION}

At present, poultry has a big part in food resources and its production is higher than the large animal production in the world. In Turkey, 270 million poultry is produced each year and about 755.000 of these are geese. In regard to poultry production, Kars Province (East Anatolia Region) accommodates $0.36 \%$ of the poultry population in Turkey, but, Kars is in first place in Turkey, if considering the goose population, with $22 \%$ (1).

Geese can be raised in many different conditions in variety of climates. Geese production plays a very important role in the economy of Kars Province in Turkey and they have been popular in the region over the years. Geese are farmed in small flocks of $20-30$ by the local people and these numbers can

Corresponding author: Assoc. Prof. Ufuk Kamber, $\mathrm{PhD}$

E-mail address: ufukkamber@hotmail.com

Present address: Food Safety and Health Department

Veterinary Faculty, Kafkas University, Kars, Turkey

Phone ++904742426836; Fax: ++ +904742426853

Copyright: (C) 2016 Kamber U. This is an open-access article published under the terms of the Creative Commons Attribution License which permits unrestricted use, distribution, and reproduction in any medium, provided the original author and source are credited.

Competing Interests: The authors have declared that no competing interests exist.

Available Online First: 6 April 2016

Published on: 15 October 2016

http://dx.doi.org/10.1515/macvetrev-2016-0078 go up to 60-100 in a flock in the villages (2). Many families living in the city center and the rural area of the Kars Province fulfill their meat requirements by consuming a large amount of goose meat in their diet in winter $(2,3,45)$ and a goose breeding station has been established in the region (4). The consumption of goose meat is rather distinctive and traditional in the region and shows dissimilarity to the rest of Turkey. The geese are raised organically in the fields and slaughtered at the beginning of winter, especially after the fall of the first snow, by individual families. After slaughtering, internal organs are eviscerated, slightly salted and hung to dry outside in the open air by the local people at home. Therefore, during the drying of geese carcasses outside in an open environment, they are exposed to dust and wind. Subsequently, dried geese carcasses are cursory stored to be consumed during the winter. Slaughtering of geese at home rather than at the poultry slaughterhouse is likely to be unhygienic, if care is not taken. Due to improper slaughtering conditions, processing usually cannot be considered as hygienic and furthermore, carcasses may be contaminated with microorganisms during the process (5).

Food intoxication is still a serious health problem in the country. According to recent reports, 
annually in the United Kingdom 17 million (31.6\% ) in Germany 23 million (28.7\%), in USA 76 million (27.9\%), in Turkey 19 million (27.8\%) and in France 17 million $(25.4 \%)$ of people are reported to be associated with food borne intoxication (6). The report of the Centre for Diseases Control and Prevention $(\mathrm{CDC})$, based on data from the USA, revealed a grand total of 18.499 laboratoryconfirmed cases of nine food-borne illnesses in 2008. Out of these laboratory-confirmed cases, the majority of food-borne illnesses were associated with Salmonellae (7.444 cases), Campylobacter (5.825 cases), Shigella (3.029 cases), Cryptosporidium (1.036 cases), E. coli 0157 (718 cases), Yersinia (164 cases), Listeria (135 cases), and Vibrio (131 cases) (6). Poultry meat is at the forefront of food intoxications. For example, between 1998-2008, the CDC received reports of 13.405 foodborne-disease outbreaks, resulting in 273.120 illnesses, 9.109 hospitalizations, and 200 deaths. The commodities implicated most commonly in the outbreaks were poultry $(10 \%)$, beef $(6.6 \%)$ and fish $(6.1 \%)(7,8)$. A recent report, by the Food Standards Agency, stated each year around 500.000 food poisoning instances, of which 244.000 could be attributed to poultry meat (6).

Microbiological studies on chicken meat and carcasses are well documented, but very few studies exist on goose meat and carcasses. The aerobic mesophilic bacteria, coagulase positive staphylococcus, Escherichia coli, Clostridium perfringens, listeria, Yersinia spp. and Salmonellae in fresh goose carcasses are investigated (9). Aydin et al. (10) showed that Campylobacter jejuni were common in the intestinal tracts of domestic geese and therefore geese have been considered as a potential reservoir for human and animal campylobacteriosis. However, these were alive birds. Turcsan et al. (11) examined goose liver samples in terms of anaerobic bacteria and clostridia, and enumerated Clostridium perfringens spores in the raw goose liver samples taken after evisceration of the birds (EB) in the slaughterhouse and after removal of blood vessels from the liver (RBVL) in the cannery. Because poultry feces contains Clostridium perfringens, the meat and viscera might be contaminated during processing (12). The samples taken after RBVL had significantly higher $(\mathrm{p}<0.05)$ spore counts than did those taken after EB, indicating contamination of the livers during the processing. The chemical and microbiological quality of fresh goose meat is investigated (13). However, recently it was reported very high $(60 \%)$ prevalence for Salmonellae in carcass in examined flocks of domestic geese (14). Furthermore, high numbers of $E$. coli bacteria in the fresh goose meat are also reported (9). Thus, it is likely that dried geese carcasses can also be contaminated by pathogen micro-organisms. In this study therefore, dried goose carcass samples were collected from the local households in Kars/Turkey and microbiologically examined in terms of public health risks.

\section{MATERIAL AND METHODS}

The dried goose carcasses were collected from the local shops and individual families. The carcasses were sampled from five different sites of each bird by excising an area of tissue as follows: 10 from neck, 12 from thigh, 10 from breast, 12 from wing and 12 samples from back of the birds. Thus, a total of 56 samples were investigated for their microbiological qualities in this study. The location of samples on the goose carcass is shown in Figure 1.

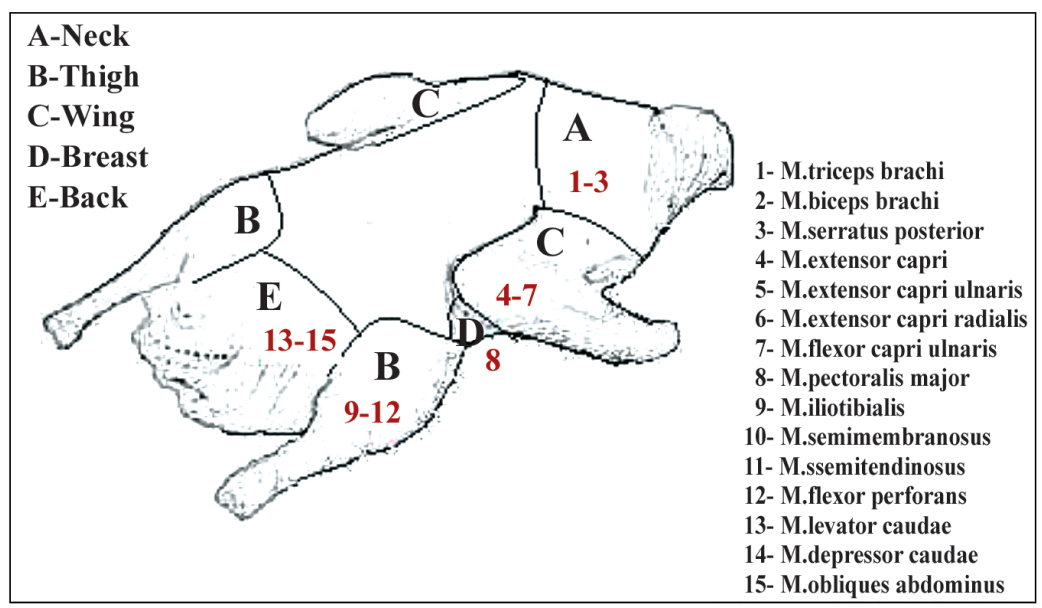

Figure 1. The location of samples on the goose carcass and muscles of parts 
Microbiological analysis of dried goose carcasses

All the samples were homogenized in sterile porcelain cups. Starting with the first suspension of $10 \mathrm{~g}$ sample in $90 \mathrm{ml}$ diluent, tenfold serial dilutions were made. Two $0.05 \mathrm{ml}$ of each of the serially diluted samples were inoculated onto Plate Count Agar (Oxoid CM325) (15) for aerobic mesophilic bacteria, using the drop plating technique (double drops resulting in $0.1 \mathrm{ml}$ per sample solution) (16). The plates were inoculated at $30^{\circ} \mathrm{C}$ for $48-72 \mathrm{~h}$ under aerobic conditions. For the Enterobacteriaceae, Violet Red Bile Glucose Agar (Oxoid CM 485) was inoculated and incubated anaerobically at $37^{\circ} \mathrm{C}$ for $24-48 \mathrm{~h}$ (17) while Violet Red Bile Agar (Oxoid CM 107) was inoculated and incubated at $30^{\circ} \mathrm{C}$ for $24-48 \mathrm{~h}$ for the coliforms (18). For the enterotoxigenic Staphylococcus aureus, Egg Yolk Tellurite emulsion (SR 54) was added into Baird Parker Agar base (Oxoid CM 275) before the inoculation and incubated at $37^{\circ} \mathrm{C}$ for $48 \mathrm{~h}$ (19), whereas Slanetz and Bartley Medium (Oxoid CM 377) was inoculated and incubated at $37^{\circ} \mathrm{C}$ for $48 \mathrm{~h}$ for the fecal streptococcus (17). Bacillus Cereus Selective Agar Base (Oxoid CM 617) was inoculated and incubated at $37^{\circ} \mathrm{C}$ for $24 \mathrm{~h}$ for the Bacillus cereus (15). Perfiringens Agar Base (Oxoid $\mathrm{CM}$ 587) was inoculated and incubated at $37^{\circ} \mathrm{C}$ for $24 \mathrm{~h}$ for the Clostridium perfringens (15). For the mould and yeast, Chloramphenical Antibiotic Supplement (Oxoid SR 78) was added to Rose Bengal Chloramphenical Agar (Oxoid CM 549): inoculated and incubated at $25^{\circ} \mathrm{C}$ for 5 days (15). The isolation of Salmonella spp. was performed following the classical methods by using two selective enrichment media of buffered pepton water $\left(37^{\circ} \mathrm{C}\right.$ for $\left.24 \mathrm{~h}\right)$ and Rappaport-Vassiliadis broth $\left(41^{\circ} \mathrm{C}\right.$ for $\left.48 \mathrm{~h}\right)($ Oxoid CM 669) $(17,18)$. Then these cultures were streaked on Hektoen Enteric
Agar (Oxoid CM 419), Brillant Green Agar (Oxoid CM 263) and XLD (Oxoid CM 469) $\left(37^{\circ} \mathrm{C}\right.$ for 24 h). No further confirmatory tests were performed since no suspected colonies of Salmonella spp. were observed.

Statistical Analysis; ANOVA was performed to analyze the significance between the mean values of the results. The results were considered as significant when $\mathrm{p}$ values were less than 0.05 .

\section{RESULTS}

The examination of dried goose carcasses showed that $100 \%$ of the samples had aerobic mesophilic bacteria at the average number of $\log _{10}$ 6.58 CFU g ${ }^{-1}$. Yeasts were found in $94.6 \%$ of the samples at an average number of $\log _{10} 4.81 \mathrm{CFU} \mathrm{g}^{-1}$. Enterobacteriaceae and enterococci were enumerated in $92.8 \%$ and $91 \%$ of the samples at the average counts of $\log _{10} 4.85$ and $3.95 \mathrm{CFU} \mathrm{g}{ }^{-1}$ respectively. Coliforms were detected in $67.8 \%$ of the samples at the average number of $\log _{10} 2.98$ CFU g ${ }^{-1}$ while clostridia were counted in $26.7 \%$ of samples at the average number of $\log _{10} 0.42 \mathrm{CFU} \mathrm{g}^{-1}$. Moulds were counted in $25 \%$ of the samples at the average numbers of $\log _{10} 0.93$ and Coagulase positive staphylococci was found in $12.5 \%$ of the samples at the average number of $\log _{10} 0.41 \mathrm{CFU} \mathrm{g}^{-1}$. Clostridium perfringens was isolated from 3.5\% of the samples at the average number of $\log _{10} 0.04$ CFU g ${ }^{-1}$. No Salmonellae and Bacillus cereus were isolated in the samples examined. These results are summarized in Table 1.

The distributions of the microorganisms in the neck, thigh, breast, wing and back samples of dried goose carcasses are shown in Figure 2 and Table 2.

Table 1. The mean numbers of microorganisms in dried goose carcasses

\begin{tabular}{|c|c|c|c|c|}
\hline Microorganisms & $\mathrm{n}$ & $\begin{array}{l}\text { Portion } \\
\%\end{array}$ & Mean + sd & $\begin{array}{l}\text { Range } \\
\text { (CFU g-1) }\end{array}$ \\
\hline Aerobic mesophilic bacteria & 56 & 100 & $6.58 \pm 0.15$ & $3.20-8.30$ \\
\hline Enterobacteriaceae & 52 & 92.8 & $4.85 \pm 0.26$ & $2.30-7.00$ \\
\hline Coliform & 38 & 67.8 & $2.98 \pm 0.31$ & $2.30-6.41$ \\
\hline C. perfringens & 2 & 3.50 & $0.04 \pm 0.03$ & $0.60-1.68$ \\
\hline Coagulase $(+)$ staphylococci & 7 & 12.5 & $0.41 \pm 0.14$ & $2.30-3.99$ \\
\hline Mould & 14 & 25.0 & $0.93 \pm 0.23$ & $2.30-6.07$ \\
\hline Yeast & 53 & 94.6 & $4.81 \pm 0.21$ & $2.30-7.62$ \\
\hline
\end{tabular}

n: Number of positive samples sd: Standard deviation 
Kamber U. and Yaman H.

Table 2. The percentage, range and standard deviations of microorganisms in goose carcass parts

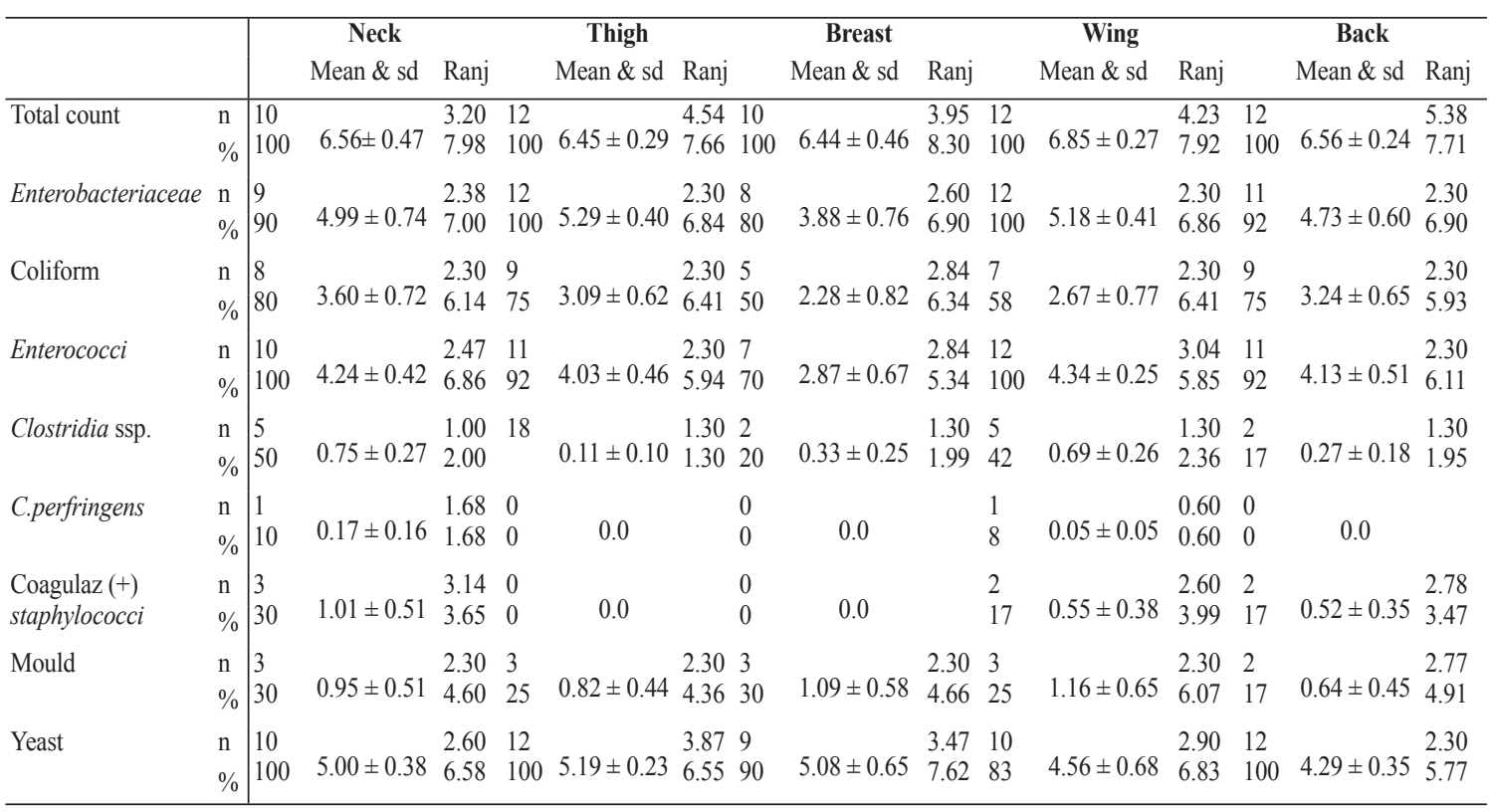

\section{DISCUSSION}

The data in the literature indicates that most of the studies about goose focus on the growth performance and carcass characteristics of different goose breeds (20-28). To our knowledge, compared to the other meat types, few studies have been conducted regarding goose meat microbiology and quality in Turkey and in other countries $(9,10,13$, 29-32). This may be probably due to goose meat rather being a seasonal product because of the limited availability of geese at other times of year (30) compared to chicken and red meat, and geese not being raised widely in Turkey and worldwide as a commercial product compared to other poultry. Thus, there is not much relevant data available related to the microbiological quality of goose meat or carcass, especially about the dried goose carcasses, in comparison to the data which exists for chicken or red meat and carcasses.

The microbiological analysis of dried goose carcasses showed that the mean counts of aerobic mesophilic bacteria $\left(\log _{10} 6.58\right)$ were higher compared to the numbers of $3.14 \mathrm{CFU} \mathrm{g}^{-1}, \log _{10} 5.25$, $4.73,3.67-4.72,4.51$ reported in the chicken carcasses by other authors $(33,34,35,36,37)$, but similarities were observed with the numbers of $10^{4}-10^{6}, 6.80 \mathrm{CFU} \mathrm{g} \mathrm{g}^{-1}, 10^{6}-10^{7}$, and $6.34-6.7 \times 10^{6}$ CFU g ${ }^{-1}$ reported in other studies $(38,39,40,41)$.

The number range of aerobic mesophilic bacteria in our dried goose carcass samples was wide (Table 1), which was also similarly reported in the traditionally processed (dried) raw goose carcass samples they analyzed (9). They reported 146 the mean number of aerobic plate counts as $5 \times 10^{6}$ $\mathrm{CFU} \mathrm{g}{ }^{-1}$ in the range of $10^{3} \mathrm{CFU} \mathrm{g}^{-1}$ to $8.74 \mathrm{CFU} \mathrm{g}^{-1}$. In the study of Xie et al. (31), they monitored spiced geese samples during the production and sale operations and reported that the total aerobic counts significantly $(\mathrm{p}<0.05)$ increased and reached up to $\log _{10} 4.86 \mathrm{CFU} \mathrm{g}^{-1}$ after four hours processing. Considering the undesirable high numbers, the microbial load of goose carcasses may cause to shorten their shelf life and pose a risk to consumers' health. The high numbers of goose carcasses may also indicate inadequate store of dried carcasses as it was observed in this study.

Enterobacteriaceae were isolated from $92.8 \%$ of the goose carcass samples examined at the average number of $\log _{10} 4.85 \mathrm{CFU} \mathrm{g}^{-1}$. Similar and higher results of $\log _{10} 4.97$ and $2.1 \times 10^{6} \mathrm{CFU} \mathrm{g}^{-1}$ are already reported (42). In comparison to these results, lower numbers of $10^{3}-10^{4} \mathrm{CFU} \mathrm{g}^{-1}$ and $\log _{10} 2.90$ were also found in the chicken carcasses by other authors (35, 43). Likewise, in the goose carcass samples, the numbers of Enterobacteriaceae ranged between the numbers of $<1.0 \times 10^{2}$ and $\geq 10^{9}$ over the $95 \%$ of the samples examined (9). These numbers were higher than the numbers obtained in this study. The presence of Enterobacteriaceae, enterococci and coliform bacteria in the goose carcasses indicates inadequate hygiene or fecal contamination.

Coliform bacteria were detected in the $67.8 \%$ of the samples at the average number of $\log _{10} 2.98$ CFU $\mathrm{g}^{-1}$. This result is similar to the results of $\log _{10} 3.13 \mathrm{CFU} \mathrm{g} \mathrm{g}^{-1}$ and $1.4 \times 10^{3}(34,44)$, but it is lower than the results of $5.1 \times 10^{4} \mathrm{CFU} \mathrm{g}{ }^{1}$ and $\log _{10} 10^{3}-10^{5}$ investigated in other studies $(38,39)$. Nair et al. (39) 
also isolated coliform bacteria from all (100\%) the samples they examined. Similar results (33) with the number of $\log _{10} 2.98 \mathrm{CFU} \mathrm{g}^{-1}$ are compatible with our results. In the study of Guven et al. (9), coliforms were detected in the range of $\geq 10^{2}$ and $<10^{7} \mathrm{CFU} \mathrm{g}^{-1}$ in the $55 \%$ of the goose carcass samples.

In terms of clostridia and Clostridium perfringens, they were isolated from $26.7 \%$ and $3.5 \%$ of the samples which were quite lower than the values of $10^{2}$ and $1.0^{1}$ found in the chicken carcasses in some studies $(37,38)$. However, in some studies the Clostridium perfringens is not found in some goose carcass samples (9). The level of $26 \%$ clostridia in the goose carcass samples showed similarity with the level of $23 \%$ clostridia isolated in the broiler samples (43). mean numbers of yeasts $\left(\log _{10} 4.81 \mathrm{CFU} \mathrm{g}^{-1}\right)$ in our study showed similarity with the mean numbers of yeast $\left(\log _{10} 4.05 \mathrm{CFU} \mathrm{g}^{-1}\right)$ reported by the same author in the spiced geese samples (31). When we analyzed the distribution of microorganisms we took into consideration the parts of dried goose carcasses.

Neck samples: Aerobic mesophilic bacteria were found in the neck samples at the number of $1.2 \times 10^{5}$ whereas aerobic mesophilic bacteria have been found at the average number of $\log _{10}$ 6.56 $\mathrm{CFU} \mathrm{g}^{-1}$ in the dried goose neck samples. Enterobacteriaceae were isolated from $90 \%$ of the goose neck samples at the average number of $\log _{10}$ 4.99 CFU g ${ }^{-1}$ while coliform bacteria were detected in $80 \%$ of the neck samples at the average number

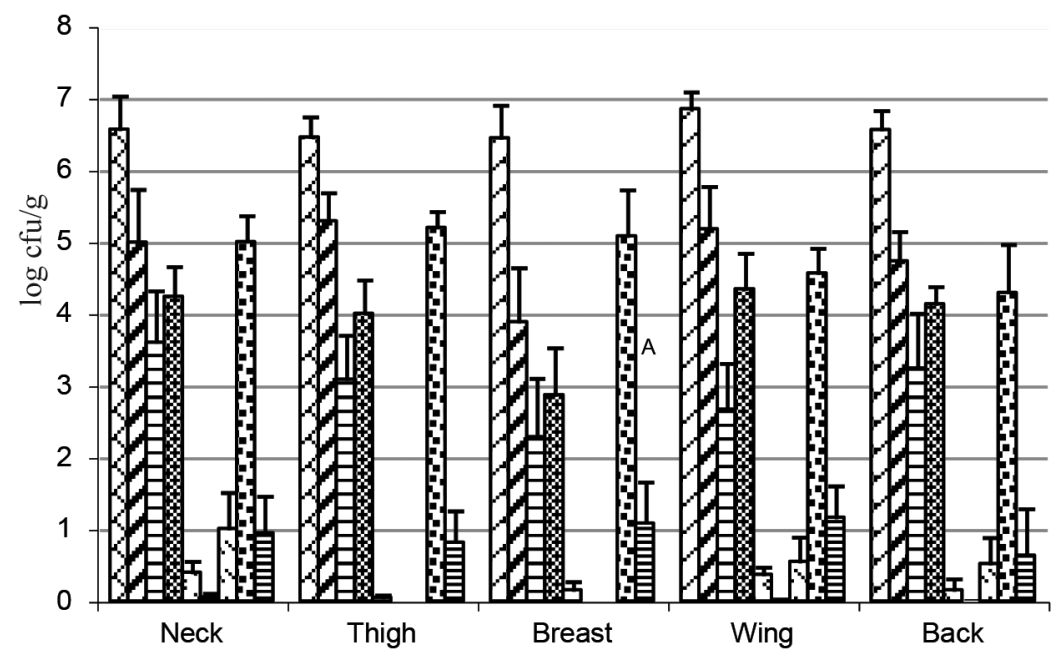

口Aerobic mesophile bacteria
口Enterobacteriacea
日Coliform
घEnterococci
口Clostridia
口.perfiringens
口Staphylocci
घeast
日Mould

Figure 2. Distribution of microorganisms in dried goose carcass parts

Coagulase positive Staphylococcus spp. were isolated from $12.5 \%$ of the samples. The average number of $\log _{10} 0.41 \mathrm{CFU} \mathrm{g}^{-1}$ was found to be similar with the results of $\log _{10}<10(89.79 \%)$ and lower than the results reported in the range of $\geq 10^{2}$ and $<10^{5}(5 \%)$ in the goose carcass samples (9). Likewise, it was quite lower than the value of $10^{2}$ reported in the goose carcasses (45). In other study (31), Staphylococcus aureus was detected in the range of $\log _{10} 2.65$ and $4.89 \mathrm{CFU} \mathrm{g}^{-1}$ in the spiced geese samples indicating that household workshop and the retail outlet were the main place for contamination.

Mould numbers were detected in the range of $\log _{10} 2.30$ and $6.07 \mathrm{CFU} \mathrm{g}^{-1}$ from the $25 \%$ of the goose carcasses while the number of yeasts was detected in the range of $\log _{10} 2.30$ and $7.62 \mathrm{CFU} \mathrm{g}^{-1}$ from the $94.6 \%$ of the goose carcass samples. Likewise, the numbers of yeast significantly increased in the spiced geese samples (31). The of $\log _{10} 3.60 \mathrm{CFU} \mathrm{g} \mathrm{g}^{-1}$ showing a similarity with the number of coliform bacteria $\left(4.7 \times 10^{3} \mathrm{CFU} \mathrm{g}^{-1}\right)$ counted in the neck samples (46). The presence of Enterobacteriaceae and coliform bacteria in the neck samples indicates inadequate hygiene during slaughtering. Enterococci were isolated in all samples and their numbers changed in the range of $\log _{10} 2.47$ and $6.86 \mathrm{CFU} \mathrm{g}^{-1}$. Clostridia were detected in $50 \%$ of the neck samples at the average number of $\log _{10} 0.75 \mathrm{CFU} \mathrm{g}^{-1}$. One of these isolates gave positive result for Clostridium perfringens at the number of $\log _{10} 1.68 \mathrm{CFU} \mathrm{g}^{-1}$ whereas the same authors (46) reported a slightly higher number of

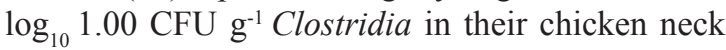
samples. Coagulase positive staphylococcus were also detected at the average number of $\log _{10} 1.01$ CFU g ${ }^{-1}$ while other investigators (46) enumerated Staphylococcus aureus in the chicken neck samples three times higher $\left(1.5 \times 103 \mathrm{CFU} \mathrm{g}^{-1}\right)$ than our result. Likewise, coagulase positive staphylococcus was 
detected at the level of $10.20 \%$ in the goose carcasses examined (9). The existence of coagulase positive staphylococcus indicates contaminations during the processes applied to the carcasses. Moulds were found in $10 \%$ of the neck samples of dried geese at the average number of $\log _{10} 0.95 \mathrm{CFU} \mathrm{g}{ }^{-1}$ while yeasts were enumerated at the average number of $\log _{10} 5.00 \mathrm{CFU} \mathrm{g}^{-1}$ which is higher than the yeast and mould number of $2.8 \times 10^{2} \mathrm{CFU} \mathrm{g}^{-1}$ reported in the neck samples of chicken examined (46).

Thigh samples: Astorga et al. (47) examined chicken thighs and reported the counts of $\log _{10} 5.56$ to $7.28 \mathrm{CFU} \mathrm{g}^{-1}$ aerobic mesophilic bacteria, whereas other authors $(38,42,46)$ reported $\log _{10} 6.4 \times 10^{5}$ CFU g-1, $3.37 \mathrm{CFU} \mathrm{g}^{-1}$ and $\log _{10} 4.6 \mathrm{CFU} \mathrm{g}^{-1}$ numbers of the aerobic mesophilic bacteria, respectively. These results are lower than the average number of $\log _{10} 6.45 \mathrm{CFU} \mathrm{g}{ }^{-1}$ in the thigh samples of goose carcasses in this study. Likewise, it was fond the numbers of $1.4 \times 10^{6} \mathrm{CFU} \mathrm{g}^{-1}$ aerobic mesophilic bacteria in the chicken thighs (44) but other author (13)reported $\log _{10} 3.65 \mathrm{CFU} \mathrm{g}^{-1}$ numbers of the aerobic mesophilic bacteria in the goose thigh samples. This is lower than the number detected in this study. Also other researchers reported the aerobic mesophilic bacteria counts of $4.5 \times 10^{7} \mathrm{CFU} \mathrm{g}^{-1}$ and $\log _{10} 6 \times 10^{7}$ $\mathrm{CFU} \mathrm{g}{ }^{-1}$ in the goose thigh samples $(45,48)$. These are higher than the number obtained in this study. Enterobacteriaceae were isolated in $100 \%$ of thigh samples at the average number of $\log _{10} 5.29 \mathrm{CFU} \mathrm{g}^{-1}$, while coliforms were detected in $75 \%$ of the thigh samples at the average number of $\log _{10} 3.09 \mathrm{CFU} \mathrm{g^{-1 }}$. Likewise, Astorga et al. (47) reported the numbers of $\log _{10} 3.49$ to $5.42 \mathrm{CFU} \mathrm{g} \mathrm{g}^{-1}$ coliform bacteria in their chicken thigh samples, whereas Kundakci et al. (46) counted the numbers of $3.7 \times 10^{3} \mathrm{CFU}$ $\mathrm{g}^{-1}$ coliforms in the chicken thighs. The number of coliforms in the goose thigh samples showed similarity with these results, but higher numbers of coliforms in the chicken thighs have also been reported at the average numbers of $4.1 \times 10^{3}$ and $1.9 \times 10^{4} \mathrm{CFU} \mathrm{g}^{-1}$ in two studies $(38,49)$. The lower number of $9.6 \times 10^{2} \mathrm{CFU} \mathrm{g}^{-1}$ coliform bacteria in the chicken thigh samples is also reported (44). This is also lower than the coliform numbers in the goose thighs samples examined in this study. Enterococci were isolated in $92 \%$ of the goose thigh samples at the average number of $\log _{10} 4.03 \mathrm{CFU} \mathrm{g}^{-1}$. This is similar with the result of $1.3 \times 10^{4}$ (44). Clostridia was detected in only one of the goose thigh samples

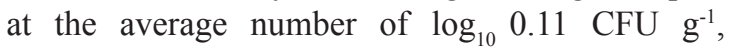
whereas other researchers $(38,46)$ found clostridia at higher numbers of $2.2 \times 10^{2}$ and $\log _{10} 1.00 \mathrm{CFU}$ $\mathrm{g}^{-1}$ respectively in the chicken thigh samples. No coagulase positive stahylococci were detected in the goose thigh samples, same as Ucar et al. (13) who 148 could not isolate any staphyloccus in the goose thigh samples, while other authors $(44,45,47)$ isolated staphylococcus at the numbers of $3.6 \times 10^{2} \mathrm{CFU} \mathrm{g}^{-1}$, $\log _{10} 2.47$ to $3.48 \mathrm{CFU} \mathrm{g}^{-1}$ and $6.2 \times 10^{2} \mathrm{CFU} \mathrm{g}^{-1}$ in the chicken thigh samples, respectively. Yeasts were detected in $100 \%$ of thigh samples at the average number of $\log _{10} 5.19 \mathrm{CFU} \mathrm{g}^{-1}$, whereas moulds were isolated only from $25 \%$ of the goose thigh samples at the average number of $\log _{10} 0.82 \mathrm{CFU} \mathrm{g} \mathrm{g}^{-1}$. In the yeast and moulds it is detected higher number of $\log 102.90$ in the chicken thigh samples (46). Other authors could not isolate any yeast and moulds from the goose thigh samples (13). This might be due to goose thigh samples being fresh and/or not stored over time.

Breast samples: In the ten goose breast samples examined, aerobic mesophilic bacteria were found at the average number of $\log _{10} 6.44 \mathrm{CFU} \mathrm{g}^{-1}$. This is higher than the number of $\log _{10} 3.88 \mathrm{CFU} \mathrm{g}^{-1}$ aerobic mesophilic bacteria found in the goose breast meat samples by Ucar et al. (13) and than the numbers of $\log _{10} 3.05 \mathrm{CFU} \mathrm{g}^{-1}, 5.0 \times 10^{4} \mathrm{CFU} \mathrm{g}^{-1}, \log _{10} 5.69 \mathrm{CFU} \mathrm{g}^{-1}$ and in the chicken breast meat samples reported by some researchers $(42,46,50)$, whereas others $(44,48)$ reported aerobic mesophilic bacteria at the numbers of $\log _{10} 7.00 \mathrm{CFU} \mathrm{g}^{-1}$, and $\max 3.9 \times 10^{7} \mathrm{CFU}$ $\mathrm{g}^{-1}$ which is higher than these all. Enterobacteriaceae were detected in $80 \%$ of the goose breast samples at the average number of $\log _{10} 3.88 \mathrm{CFU} \mathrm{g} \mathrm{g}^{-1}$ Other authors enumerated Enterobacteriaceae in the chicken breast-wing samples in the range numbers of 2.0-3.0 CFU g-1 which is lower than the result in this study (50). Half of the goose breast samples contained coliform bacteria at the average number of $\log _{10} 2.28 \mathrm{CFU} \mathrm{g}{ }^{-1}$ which is lower than the result of $3.5 \times 10^{3}$ and $1.4 \times 10^{3} \mathrm{CFU} \mathrm{g}^{-1}$ found in the breast samples $(44,46)$. Enterococci were isolated from $70 \%$ of the breast samples at the average number of $\log _{10} 2.87 \mathrm{CFU} \mathrm{g} \mathrm{g}^{-1}$ which is lower than the number of enterococci $\left(2.0 \times 10^{5} \mathrm{CFU} \mathrm{g}^{-1}\right)$ reported by Sagun et al. (44) in the chicken breast samples. Clostridia were isolated from $20 \%$ of the goose breast samples at the average number of $\log _{10} 0.33$ CFU g ${ }^{-1}$. Coagulase positive staphylococci could not be isolated from the goose breast samples. However, some authors $(44,46)$ reported the presence of staphylococci in the chicken breast samples at the numbers of $1.3 \times 10^{3}$ and $5.0 \times 10^{2}$ $\mathrm{CFU} \mathrm{\textrm {g } ^ { - 1 }}$ respectively. Moulds were isolated from only $30 \%$ of the samples at the average number of $\log _{10} 1.09 \mathrm{CFU} \mathrm{g} \mathrm{g}^{-1}$ and yeast from $90 \%$ of the samples at the average number of $\log _{10} 5.08$ CFU g ${ }^{-1}$. Gallo et al. (50) found yeast-moulds at the lower numbers of $10^{2}-10^{4} \mathrm{CFU} \mathrm{g^{-1 }}$ in the chicken breast samples. However, Ucar et al. (13) could not isolate yeast and moulds in their goose meat samples. This could be due to samples being fresh goose meat and/or not stored over time. 
Wing samples: In the twelve goose wing samples, aerobic mesophilic bacteria were enumerated at the average number of $\log _{10} 6.85 \mathrm{CFU} \mathrm{g}^{-1}$. It was reported (13) a lower number of $\log _{10} 3.82 \mathrm{CFU} \mathrm{g}^{-1}$ aerobic mesophilic bacteria in their goose samples, while some researchers $(45,47,50)$, isolated aerobic mesophilic bacteria at the numbers of 6.41 CFU g ${ }^{-1}, \log _{10} 5.56$ to 7.28 and $1.3 \times 10^{8} \mathrm{CFU} \mathrm{g}^{-1}$ in the chicken samples, respectively. These results are lower than our result in this study. Enterococci were detected in $100 \%$ of goose wing samples at the average number of $\log _{10} 5.18 \mathrm{CFU} \mathrm{g}^{-1}$, whereas Gallo et al. (50) reported lower numbers of $10^{2}-$ $10^{3} \mathrm{CFU} \mathrm{g}^{-1}$ in the chicken wing samples. Coliform bacteria were counted at the average number of $\log _{10}$ $2.67 \mathrm{CFU} \mathrm{g}^{-1}$ in $58 \%$ of the goose wing samples. Other investigators (47) counted coliform bacteria in the range numbers of $\log _{10} 3.49$ to $5.42 \mathrm{CFU} \mathrm{g}^{-1}$ which are higher than the result found in this study. Enterococci were detected in all goose wing samples at the average number of $\log _{10} 4.34 \mathrm{CFU} \mathrm{g}^{-1}$, while clostridia were isolated from $42 \%$ of the wing samples at the average number of $\log _{10} 0.69 \mathrm{CFU} \mathrm{g}^{-1}$. The highest numbers of clostridia were isolated from the wing parts of goose carcasses in this study, but only one of these isolates was identified as Clostridium perfringens at the number of $\log _{10} 0.60$ CFU g-1 ${ }^{-1}$ Likewise, coagulase positive staphylococci were isolated only from two wing goose samples

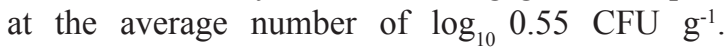
However, it is reported that there is no isolate of staphylococci in goose wing samples (13). In other studies $(45,47)$ Staphylococcus aureus were found at the max. number of $3.48 \mathrm{CFU} \mathrm{g}^{-1}$ and $8.8 \times 10^{2}$ $\mathrm{CFU} \mathrm{g}^{-1}$ respectively, which is quite higher than the number of staphylococci in our study. Moulds were counted at an average number of $\log _{10} 1.16 \mathrm{CFU}$ $\mathrm{g}^{-1}$ from $25 \%$ of the wing samples, while yeasts were enumerated from $83 \%$ of the wing samples at the average number of $\log _{10} 4.56 \mathrm{CFU} \mathrm{g}{ }^{-1}$. On the contrary, Ucar et al. (13) could not detect yeast and moulds in their goose wing samples. On other study (50), the number of yeasts $(\log 10$ 2.00-4.00 CFU $\mathrm{g}-1)$ in the chicken wing samples is higher than the result obtained in this study.

Back samples: The back samples examined revealed aerobic mesophilic bacteria at the number of $\log _{10} 6.56 \mathrm{CFU} \mathrm{g}^{-1}$. This result shows similarity with the result of $\log _{10} 6.25 \mathrm{CFU} \mathrm{g}^{-1}(50)$. Enterobacteriaceae were isolated from $92 \%$ of the back samples at the mean number of $\log _{10} 4.73 \mathrm{CFU}$ $\mathrm{g}^{-1}$ which is higher than the numbers of $10^{2}-10^{3} \mathrm{CFU}$ $\mathrm{g}^{-1}$ Enterobacteriaceae reported in the back samples by the same researcher (50). Coliform bacteria were isolated from $75 \%$ of the back samples at the mean number of $\log _{10} 3.24 \mathrm{CFU} \mathrm{g}^{1}$. Enterobacteriaceae and enterococci were isolated from $92 \%$ of the samples at the mean numbers of $\log _{10} 0.27$ and $4.13 \mathrm{CFU} \mathrm{g}^{-1}$ respectively. Coagulase positive staphylococci and clostridia spp. were isolated from $17 \%$ of the back samples at the mean numbers of $\log _{10} 0.52$ and 0.27 CFU $\mathrm{g}^{-1}$ respectively. Moulds were counted at the mean number of $\log _{10} 0.64 \mathrm{CFU} \mathrm{g}^{-1}$ from $25 \%$ of the samples examined. Yeasts were detected in all samples at the mean number of $\log _{10} 4.295 \mathrm{CFU} \mathrm{g}^{-1}$ were similar to other reported study (50).

Based on all these results and statistical analysis, there are differences between the parts of goose carcasses. Aerobic mesophilic bacteria have been found to be at higher numbers in the neck and wing samples. This makes us think that the carcasses have been dried upside down. In general, aerobic mesophilic bacteria were enumerated at the lowest number of $\log _{10} 6.44 \mathrm{CFU} \mathrm{g}^{-1}$ in breast samples, while the highest number of $\log _{10} 6.85 \mathrm{CFU} \mathrm{g}^{-1}$ was detected in wing samples. Enterobacteriaceae were found at the lowest number of $\log _{10} 3.88 \mathrm{CFU} \mathrm{g}^{-1}$ in the breast samples, while the highest number of $\log _{10} 5.29 \mathrm{CFU} \mathrm{g}^{-1}$ was detected in the thigh samples. Coliform bacteria were detected the most in the neck samples with the highest number of $\log _{10} 3.60 \mathrm{CFU}$ $\mathrm{g}^{-1}$, while the lowest number of $\log _{10} 2.28 \mathrm{CFU} \mathrm{\textrm {g } ^ { - 1 }}$ was found least in the neck samples out of the five. Enterococci were counted at the lowest count of $\log _{10} 2.87 \mathrm{CFU} \mathrm{g}^{-1}$ in the breast samples, whereas the highest number of $\log _{10} 4.34 \mathrm{CFU} \mathrm{g}^{-1}$ was observed in the wing samples. Enterococci were detected in all wing samples, while their detection was much less in the breast samples. Clostridia spp. were counted less in the thigh samples with the lowest count of $\log _{10} 0.01 \mathrm{CFU} \mathrm{g}^{-1}$ and the highest count of $\log _{10} 0.75 \mathrm{CFU} \mathrm{\textrm {g } ^ { - 1 }}$ was found in the neck samples. Clostridia spp. was detected the most in the neck and wing samples compared to the thigh samples. Clostridium perfringens was isolated from one of the neck and wing samples, with the higher number

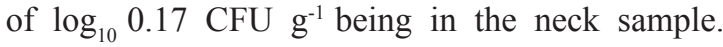
Staphylococci could not be detected from the thigh and breast samples, while the highest number of $\log _{10} 1.01 \mathrm{CFU} \mathrm{g}^{-1}$ was enumerated in the neck samples. Moulds were found less at the lowest count of $\log _{10} 0.64 \mathrm{CFU} \mathrm{g}^{-1}$ in the back samples, whereas the highest number of $\log _{10} 1.16 \mathrm{CFU} \mathrm{g}^{-1}$ was found in the wing samples and were isolated the most in the samples of neck, thigh, breast and wing. Yeasts were isolated from all the samples and were counted at the lowest number of $\log _{10} 4.29 \mathrm{CFU} \mathrm{g}^{-1}$ in the neck samples and the highest number of $\log _{10} 5.19$ $\mathrm{CFU} \mathrm{g}^{-1}$ in the thigh samples. Considering the small differences in the counts of yeast in the samples, it is presumed that the dried goose carcasses examined might have been contaminated with yeast during the storage rather than during the processing. 


\section{CONCLUSION}

In conclusion, the microbiological analysis of dried goose carcasses showed relatively high numbers of bacteria in the goose carcasses in this study. Based on undesirable numbers of $10^{7}-10^{8}$ $\mathrm{CFU} \mathrm{g}^{-1}$ in the meat products, the microbial load of goose carcasses may indicate inadequate handling and storage of dried carcasses, and cause to shorten their shelf life. The presence of Enterobacteriaceae, enterococci and coliform bacteria in the goose carcasses indicates inadequate hygiene and/or fecal contamination which require attention in terms of posing a risk to consumer's health.

\section{ACKNOWLEDGMENT}

This work was supported by the Turkey Scientific Research and Technology Council (Project number: VHAG-1815)

\section{REFERENCES}

1. Anon. (2015). Turkey Statistical Institute database Internet web site statistics http://tuikapp.tuik.gov. tr/hayvancilikapp/hayvancilik.zul, Access date: 09.03.2015.

2. Selcuk, E., Akyurt, I., Geliyi, C. (1983). Goose breeding. Ministry of agriculture, forestry agricultural affairs publication, Ankara.

3. Kirmizibayrak, T. (2002). Goose slaughter and carcass traits of native breeds reared in the hands of the people of Kars. Turk J. Vet. Anim. Sci. 26(1): 667670.

4. Gonul, T., Yuceyigit, E., Aksu, M., Kapucu, A. (1995). Goose. Goose breding station report. TKV Publication, Ankara.

5. Gulbaz, G., Kamber, U. (2008). Experimentally fermented sausage from goose meat and quality attributes. J Muscle Foods, 19(3): 247-260. http://dx.doi.org/10.1111/j.1745-4573.2008.00107.x

6. Anon. (2014). Centers for disease control and prevention. Web page statistics http://www.cdc.gov/ foodborneburden/surveillance-systems.html, Access date: 06.05.2014.

7. Anon. (2013). Surveillance for foodborne disease outbreaks-United States, 1998-2008. Centers for disease. Control and Prevention. MMRV. 62, 1-6.

8. Painter, J. A., Hoekstra, R. M., Ayers, T., Tauxe, R. V., Braden, C. R., Angulo, F. J., Griffin, P. M. (2013). Attribution of foodborne illnesses, hospitalizations and deaths to food commodities by using outbreak data US 1998-2008. Emerging Infect. Dis. 19(3): 407-415.

http://dx.doi.org/10.3201/eid1903.111866

PMid:23622497 PMCid:PMC3647642
9. Guven, G., Gulmez, M., Duman, B., Sezer, C. (2003). The microbiological contamination of traditionally processed raw goose carcasses marketed in Kars. Internet J. Food Safety. 3, 4-7.

10. Aydin, F., Atabay, H. I, Akan, M. (1992). The isolation and characterization of $\mathrm{C}$. jejuni from domestic geese (Anser anser). J. Appl. Microbiol. 90(4): 637-642. http://dx.doi.org/10.1046/j.1365-2672.2001.01293.x

11. Turcsan, J., Varga, L., Turcsan, Z., Szigeti, J., Farkas, L. (2001). Occurrence of anaerobic bacterial, clostridia, and C. perfringens spores in raw goose livers from a poultry processing plant in Hungary. $\mathrm{J}$. Food Protect. 64(8): 1252-1254. PMid:11510671

12. Radovcic, P. E., Novak, M. L. (1991). Prevalence and epidemiological significance of clostridium bacteria poultry. Vet. Stanica. 22, 259-264.

13. Ucar, G., Gurbuz, Ü., Guner, A., Dogruer, Y. (2001). Some chemical and microbiological quality characteristics of domestic goose (Anser domesticus) meat. Vet. Bil. Derg. 17(4): 31-36.

14. Mann, E. D., Mcnabb, G. D. (1984). Prevalence of Salmonellae contamination in market-ready geese in Manitoba. Avian Dis. 28(4): 978-983.

http://dx.doi.org/10.2307/1590274

PMid:6525139

15. Anon. (1990). The oxoid manuel of culture media (6. Ed ed.). England: Published by Uniped Limited.

16. Reuter, G. (1970). Microbiologische analyse von lebensmitteln mit selektiven medien. Archiv. Lebensmittellhyg. 21, 30-35.

17. Baumgart, H. J. (1986). Mikrobiologische untersuchung lebensmitteln. Behr's Verlag, Hamburg.

18. Harrigan, W. F., Cance, M. E. (1976). Laboratory methods in food and dairy microbiology. Academic Press, London.

19. Vanderzant, C., Splittstoesser, D. F. (1992). Compendium of methods for the microbiological examination of food. American Public Health Association, Washington. PMid:22059567

20. Isguzar, E., Pingel. H. (2003). Growth., carcass composition and nutrient content of meat of different local geese in Isparta region of Turkey. Arch. Tierz. D.storf. 46(1): 71-76.

21. Tilki, M., Saatci, M., Kirmizibayrak, T., Aksoy, A. R. (2005). Effect of age on growth and carcass composition of native Turkish geese. Arch. Geflügelk. $69,77-83$.

22. Sahin., E. H., Yardimci, M. (2009). Effect of kefir as a probiotic on growth performance and carcass characteristics in geese (Anser anser). J. Anim. Vet. Adv. 8(3): 562-567. 
23. Liu, B. Y., Wang, Z. Y., Yang, H. M., Wang, J. M., $\mathrm{Xu}$, D., Zhang, R., Wang, Q. (2011). Influence of rearing system on growth performance, carcass traits, and meat quality of Yangzhou geese. Poultry Sci. 90 (3): $653-659$.

http://dx.doi.org/10.3382/ps.2009-00591

PMid:21325238

24. Yakan, A., D. Elmali, D. A., Elmali, M., Sahin, T., Can, C. (2012). Carcass and meat quality characteristics of white and multicolor geese under local breeder conditions. Kafkas Univ. Vet. Fak. Derg. 18(4): 663-670.

25. Geldenhuys, G., Hoffman, L. C., Muller, N. (2013). The effect of season, sex, and portion on the carcass characteristics, $\mathrm{pH}$, color, and proximate composition of Egyptian goose (Alopochen aegyptiacus) meat. Poultry Sci. 92(12): 3283-3291. http://dx.doi.org/10.3382/ps.2013-03443 PMid:24235240

26. Buzala, M., Adamski, M., Janicki, B. (2014). Characteristics of performance traits and the quality of meat and fat in oat Polish geese. World's Poultry Sci J. 70(3): 531-542. http://dx.doi.org/10.1017/S0043933914000580

27. Uhlirova, L., Tumova, E. (2014). The effect of genotype and sex on performance and meat composition of geese. Acta Fytotechn. Zootechn. 17(2): 52-54.

http://dx.doi.org/10.15414/afz.2014.17.02.52-54

28. Sarica, M., Boz, M. A., Yamak, U. S. (2014). Pied white goose meat quality and some blood parameters in Yozgat. Anadolu J. Agr. Sci. 29: 147-153.

http://dx.doi.org/10.7161/anajas.2014.29.2.147-153

29. Elmali, M., Yaman, H., Ulukanli, Z., Genctav, K. (2004). Isolation and identification of C.jejuni in goose carcass, goose cloaka, goose bedding and goose, chicken and quail eggs. Vet. Bil. Derg. 20(4): $47-52$.

30. Eblen, D. R., Levine, P., Rose, B. E., Saini, P., Mageau, R., Hill, W. E. (2005). Nationwide microbiological baseline data collected by sponge sampling during 1997-1998 for cattle, swine, turkeys and geese. J. Food Protec. 68(9): 1848-1853. PMid:16161683

31. Xie, H., Bu, L., Zhong, L. Z., Zhang, Y., Lin, J., Li, Z. (2013). Tracking microorganisms in production and sale operations of spiced geese. Food and Nutr. 4(9): 950-955.

http://dx.doi.org/10.4236/fns.2013.49123

32. Jamali, H., Radmehr, B., Ismail, S. (2014). Prevalence and antimicrobial resistance of Listeria, Salmonella and Yersinia spp. isolates in ducks and geese. Poultry Sci. 93(4): 1023-1030.

http://dx.doi.org/10.3382/ps.2013-03699

PMid:24706981
33. Izat, A. L., Colberg, M., Driggers, C. D., Thomas, R. A. (1989). Effects of sampling method and feed withdrawal period on recovery of microorganisms from poultry carcasses. J. Food Protec. 52(7): 480-483.

34. Fliss, I., Simard, R. E., Ettriki, A. (1991). Microbiological quality of different fresh meat species in Tunisian slaughterhouses and markets, J. Food Protec. 54(10): 773-777.

35. James, W. O., Prucha, J. C., Brewer, R. L., Williams, W. O., Christensen, W. A., Thaler, A. M., Hogue, A. T. (1992). Effects of counter current scalding and post scald spray on the bacteriologic profile of raw chicken carcasses. JAVMA. 201(5): 705-708.

PMid:1399771

36. Kozačinski, L., Hadžiosmanović, M., Zdolec, N. (2006). Microbiological quality of poultry meat on the Croatian market. Veterinarski Arhiv., 76(4): 305-313.

37. Cohen, N., Bouchrif, B., Hassar, M. Karib, H. (2007). Comparative study of microbiological quality of raw poultry meat at various seasons and for different slaughtering processes in Casablanca (Morocco). J. Appl. Poult. Res. 16(4): 502-508. http://dx.doi.org/10.3382/japr.2006-00061

38. Yucel, A. (1988). Microbial contamination of chicken carcasses sold on the market on research. Vet. Hek. Dern. Derg. 3-4(58): 57-65.

39. Nair, K. S., Rao, D. N., Haleem. M. A. (1990). Bacteriological quality of dressed chicken. Indian Vet J. 67(1): 55-58.

40. Vorster, S. M., Greebe, R. P., Nortje. G. L. (1994). Incidence of $\mathrm{S}$. aureus and $\mathrm{E}$. coli in ground beef, broilers and processed meats in Pretoria South Africa. J. Food Protec. 57(4): 305-310.

41. Yashoda, K. P., Sachindra, N. M., Sakharez, P. Z., Rao, D. N. (2001). Microbiological quality of broiler chicken carcasses processed hygienically in a small scale poultry processing unit. J. Food Quality. 24(3): 249-259.

http://dx.doi.org/10.1111/j.1745-4557.2001.tb00606.x

42. Lillard, H. S. (1988). Comparison of sampling methods and implications for bacterial decontamination of poultry carcasses by rinsing. J. Food Protec. 51(5): 405-408.

43. Yurtyeri, A. (1980). Research on surface microflora of broilers packed. Vet. Hek. Derg. 50(1): 45-63.

44. Sagun, E., Sancak, Y. C., Ekici, K., Durmaz, H. (1996). Van province consumed chicken breast meat of rump meat a study on hygienic quality. YYU. Vet. Fak. Derg. 7(1-2): 62-66.

45. Gulin, S. (2009). Sold in the market, chemical and microbiological quality and sensory their expiry dates of fresh poultry meat preparations. Uludag Univ. Vet. Fak. Derg. 28, 19-24. 
46. Kundakci, A., Yucel, Y. (1991). Microflora stored in cold conditions and quality of chicken meat offered for sale. Int Symposium $2^{\text {th }}$ Food, 17-20 September (pp. 191-200) Bursa, Turkey.

47. Astorga, M. A., Capita, R., Calleja, A.C., Moreno, B., Gaecia-Fernandez, M. C. (2002). Microbiological quality of retail chicken by products in Spain. Meat Sci. 62(1): 45-50.

http://dx.doi.org/10.1016/S0309-1740(01)00225-X

48. Efe, M., Gumussoy, K. S. (2005). Microbiological analysis of poultry meat available for consumption in Ankara Garrison. Health Sci. 14, 151-157.
49. Anar, S., Carl1, T., Sen, A., Eyigör, A. (1992). Presented to the consumption of chicken S.aureus and E.coli type II study on isolation in Bursa. Uludag Univ. Vet. Fak. Derg. 11(2): 135-143.

50. Gallo, 1., Schmit, R. E., Lorenz, W. S. (1988). Microbial spoilage of refrigerated fresh broilers. Part I. Bacterial flora and growth during storage. Leben. Wissensch. Technol. 21, 216-223. 